\title{
CONGESTIVE CARDIAC FAILURE INDUCED BY OESTROGEN THERAPY
}

\author{
M. Tessa Morrell, B.A.(Cantab.) \\ Medical Student, \\ Oxford University Clinical School \\ S. C. Truelove, M.A., M.D.(Cantab.), F.R.C.P.(Lond.) \\ Nuffield Department of Clinical Medicine, \\ Oxford University
}

(from the Radcliffe Infirmary, Oxford)

\begin{abstract}
A RECENT controlled therapeutic trial showed that, in men with a history of chronic duodenal ulcer for less than ro years, treatment with stilbœstrol in a dose of $0.5 \mathrm{mg}$. b.d. for six months had a beneficial effect in the majority (Truelove, 1960). Side-effects, consisting of diminution or loss of sexual potency, and of gynæcomastia, were liable to occur. It was pointed out that this approach to treatment should be regarded as experimental and that its practical application would probably depend on whether equally good results could be obtained with a shorter course of treatment to minimize the side-effects. Alternatively, one of the non-feminizing chemical analogues of the œstrogens may be found beneficial.
\end{abstract}

In certain circumstances, treatment with stilbœstrol can be dangerous. An elderly woman who had been treated by her general practitioner for a peptic ulcer, with stilbœstrol I.o mg. t.d.s., later reduced to I $\mathrm{mg}$. b.d., for a total time of two months, was seen as an out-patient with congestive cardiac failure arising as a side-effect of therapy.

\section{Case History}

A 72-year-old woman had been a chronic bronchitic for 20 years but had had no attacks of bronchitis for the last three years. She was dyspnœic after climbing a flight of 14 stairs or when walking up an incline, and had had slight ankle swelling during the evenings for three years. She lived in a top-storey flat and did her own housework except for help on one day a week.

In 1954 she presented with a 5 to Io-year history of dyspepsia. A barium meal at that time showed the presence of a duodenal ulcer. Since then dyspeptic symptoms had been relieved by diet and alkalis until the last attack in 1960, when her general practitioner introduced stilbœstrol I mg. t.d.s., which quickly controlled the symptoms. Thereafter, the dose was reduced to I mg. b.d.

Two months after stilbœstrol therapy was instituted, the patient went to her doctor complaining of severe breathlessness and swelling of the legs and ankles. He discontinued stilbœstrol therapy and referred her to the Radcliffe Infirmary, where she was seen three days later.

She had had severe dyspnœa on exertion for a fortnight; she could climb only four stairs without stopping, and she had been very frightened by paroxysmal noc- turnal dyspnœa. On exertion, both sides of her neck ' filled out' and felt tight, and this was associated with pain which radiated to the jaw and right shoulder and which was relieved by resting for a few minutes. A fortnight before she was seen, she ' hadn't passed enough water'. There had been persistent œdema of the legs and ankles for two weeks. She had become increasingly tired. There had been vaginal bleeding on the day following the cessation of stilbostrol therapy. At this time dyspeptic symptoms were absent.

Physical examination showed that she was an obese woman, weighing I I st. $4 \mathrm{lb}$., with signs of congestive cardiac failure. There was slight pallor of the mucous membranes and slight central cyanosis. The nipples were deeply pigmented. The pulse was regular with a normal rate and the blood pressure was 140/80. There was clinical evidence of cardiomegaly; the apex beat was 41 in. from the mid-line, lateral to the midclavicular line. Both heart sounds were normal and there were no murmurs. The jugular venous pressure was raised $I$ in. There was gross pitting odema of both feet and legs up to the knees. The liver was not palpable. Abnormal findings in the respiratory system were some scattered rhonchi and a few coarse crepitations at the left base posteriorly.

No drug therapy was given but she was advised to rest as much as possible.

During the following six weeks her weight fell to Io st. $9 \mathrm{lb}$., while the odema subsided to a large extent. The dyspnœea decreased and there was no further experience of paroxysmal nocturnal dyspnoea.

Dyspepsia had not recurred, but a barium meal showed that the pyloric canal and base of the duodenal cap were deformed and there was a small pyloric ulcer present.

Two months after the patient was first seen reexamination showed that there was no cyanosis, the apex beat was $3 \frac{1}{2}$ in. from the mid-line in the midclavicular line and fifth intercostal space, there was some ankle œdema, the jugular venous pressure was not raised, and there were no abnormal signs in the respiratory system.

Investigations carried out at that time gave the results: $\mathrm{Hb} 78 \%$; PCV $37 \%$; W.B.C. $5,000 / \mathrm{cu} . \mathrm{mm}$; blood urea $48 \mathrm{mg}$./ $100 \mathrm{ml}$.; plasma chloride I $5 \mathrm{mEq} . / \mathrm{l}$;; plasma bicarbonate $17 \mathrm{mEq}$. $/ 1$.; plasma protein electrophoresis, normal pattern. CSU: no protein, cells, casts or crystals. Chest $\mathrm{X}$-ray showed the heart to be a little enlarged and the lung fields clear. The ECG was reported as showing evidence of chronic myocardial strain. Respiratory function was within normal limits 
for a person of this age, as judged by respiratory tests carried out by Dr. R. Marshall.

When seen again, ten months later, she was well apart from occasional indigestion. There had been no recurrence of the heart failure and she was fully active for her age.

\section{Comment}

When first seen the patent had symptoms and signs of congestive cardiac failure. Because of its development during the course of stilbœstrol therapy, which had produced nipple pigmentation and withdrawal vaginal bleeding as side-effects, there was a strong suggestion that the congestive cardiac failure had been precipitated by retention of salt and water caused by the stilbœstrol.

In order to strengthen the diagnosis, it was decided to withhold all treatment initially except advice to rest. One week later the patient's condition had considerably improved, so this policy was continued with a satisfactory outcome.

Investigations were carried out after two months in order to estimate, as nearly as possible, the previous condition of the patient and the reason for the onset of congestive cardiac failure as a sideeffect of a short course of therapy with a comparatively small dose of stilbœstrol.

Slight enlargement of the heart, ECG evidence of myocardial strain and previous history of mild dyspnoea and ankle swelling suggest that the patient had a poor cardiac reserve. In these circumstances, the water retention caused by a small dose of stilbœstrol sufficed to overload the circulatory system and cause congestive cardiac failure. The water retained was reflected by the loss of weight of II lb. (equivalent to approximately $5 \mathrm{l}$. of water) after treatment with stilbœstrol was stopped.

\section{Discussion}

Mild œedema is well known as a side-effect of œstrogen therapy. Massive œdema associated with congestive cardiac failure is uncommon and, in nearly every case, has occurred only in patients with pre-existing heart disease who have been on prolonged therapy.

In a study of intensive œstrogen therapy for carcinoma of the breast, Kennedy and Nathanson (1953) found that peripheral œdema of varying severity occurred in one-third of patients. The usual dose was $15 \mathrm{mg}$. of stilbœstrol or its equivalent daily, with a range of 4 to $400 \mathrm{mg}$. daily. All patients except 20 had treatment for at least a month and several for more than a year. The incidence of œdema rose with age. In 17 patients $(9 \%)$ the œdema resulted in congestive cardiac failure or exaggerated an existing mild cardiac decompensation, and five patients, who had no evidence of failure before the beginning of treatment, died of congestive cardiac failure which could not be attributed to the effects of the carcinoma. Wallach and Henneman (1959) recorded an incidence of œedema in $4 \%$ of 292 post-menopausal women on œstrogen therapy. The doses of œstrogen and the lengths of treatment both varied considerably.
Hurxthal and Smith (1952) reported pulmonas congestion developing in a 29-year-old woman with rheumatic heart disease and mitral stenosis, after treatment with $25 \mathrm{mg}$. of stilbœstrol daily for three months.

Four cases of acute congestive failure ha $\overrightarrow{\overline{\sqrt{3}}}$ occurred in men treated with diethyl stilbœst㿭l for carcinoma of the prostate. Three of the patients had pre-existing heart disease (cited Kennedy and Nathanson).

The occurrence of congestive heart failure $\mathbb{\mathbf { m }}$ patients who have had no obvious evidence off cardiac damage before the institution of œstrogen therapy may be explained by the reasonable supposition that in such patients the cardiac reserve is minimal, and that the increase in blood volun brought about by œstrogen treatment increases the work of the heart sufficiently to enhance the existing - myocardial ischæmia. This view is supported the fact that cardiac failure arising as a cono plication of œstrogen therapy occurs mainly elderly patients. Estrogen-induced congestive failure can be controlled by a low-salt diet, diuretiE़ and digitalis, or by ending œstrogen therapy.

Edema resulting from œstrogen therapy $\stackrel{\circ}{18}$ caused by the retention of salt and water, the first indications being an increase in body weight an in some patients, a noticeable decrease in the urinary volume. In a normal subject there may be an increase of 6-8 lb. in body weight before œdenga is manifest. Increases in weight from $2-3$ gkg $\left(4 \frac{1}{2}-6 \frac{1}{2} \mathrm{lb}\right.$.) to $8-9 \mathrm{~kg}$. $\left(18 \frac{1}{2}-20 \frac{1}{2} \mathrm{lb}\right.$.) have been noted in patients on œstrogen therapy, those with larger gains of weight showing œdema (Germes, 1948). Rise in weight reflecting the increase body water can be induced in normal subjects the administration of astrogens. Klopper (195\%) gave I mg. œstriol daily for four days to post menopausal women. In a typical case, after thre days the plasma water had risen from the normal of 25.4 to 30.5 and a week later had decreased 29.3 (units of measurement not specified).

In I I ' normal' subjects without renal, cardiace or hepatic disease or other disease likely to affect the sodium, chloride and water balance, who wees given œstradiol monobenzoate ro $\mathrm{mg}$. in oil i.m. daily for one week, there was a significant, limited salt and water retention followed by diuresis white the injections were being continued (Preedy and Aitken, 1956). This suggests that in the normal subject the body is able to accommodate to ex genous œstrogens and that, after an interval of a few days, there is an increase in the metabolfes processes which inactivate steroids.

There is some evidence that œema is intimate connected with liver function. Hepatic congestion is one of the earliest changes in congestive cardia failure and the resulting hypoxia of the liver cells probably leads to decreased efficiency in metabolisn including the denaturation of both endogenous and administered œstrogens, which therefore exert an unduly prolonged action in these circumstance. Experimentally, hepatic congestion specificallo appears to be necessary for sustained œdem 
formation (Laragh, 1956), and the role of hepatic congestion in diminishing the rate of inactivation of exogenous salt-retaining steroids is supported by the work of Yates, Urquart and Herbst (1958). In vitro, reduction of ring $\mathrm{A}$ (taken as a representative reaction of inactivation) of desoxycorticosterone, cortisone and hydrocortisone was severely impaired in livers taken from rats which had been in experimental hepatic congestion.

Preedy and Aitken (1956) found marked and sustained retention of sodium, chloride and water in patients with constrictive pericarditis and in patients with cardiac failure due to other causes who were treated in the same way as their normal subjects (vide supra) who had only a slight salt and water retention followed by diuresis.

It is probable that, in patients with a decreased cardiac reserve, stilbœstrol first causes an increase in salt and water retention which results in an increased blood volume and definitive hepatic congestion, which in turn markedly reduces the capacity of the liver to adapt to the increased concentration of stilbœstrol. Inactivation of stilbœstrol being inadequate, the increased salt and water retention is sustained and gives rise to massive œdema with congestive cardiac failure. The vicious circle encouraged by œstrogen therapy can be presented diagrammatically as follows:

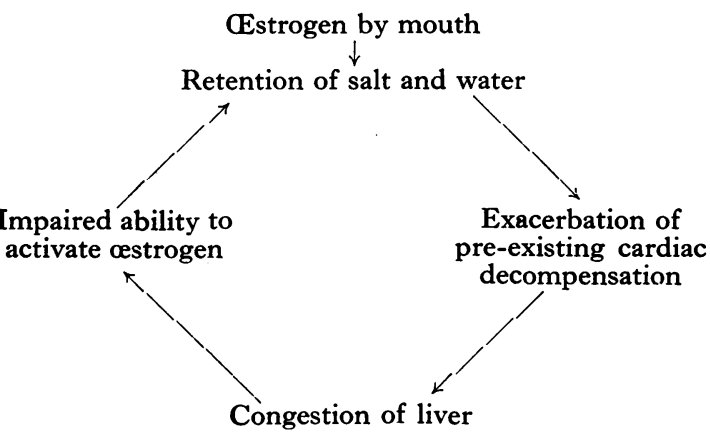

\section{Summary}

A patient treated with stilbœstrol for a duodenal ulcer presented with massive œdema and congestive cardiac failure which subsided when treatment was discontinued. Evidence from the history and subsequent investigations suggest that there was initially a poor cardiac reserve and ischæmic heart disease. Edema and congestive cardiac failure due to water retention may occur as a side-effect of stilbœstrol therapy. It is interesting that in this case complications ensued after only a small dose had been given for a short time.

Possible ætiological factors are discussed.

TABLE

Results of Lung Function Tests (Dr. R. Marshall)

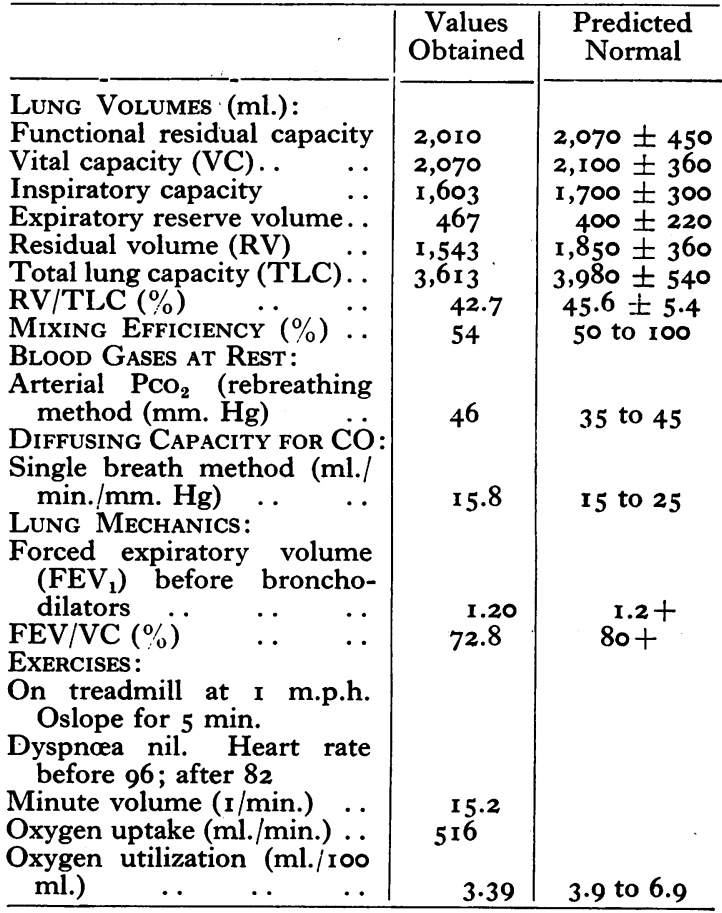

Comment. The lung function is within normal limits for this patient's nge.

\section{REFERENCES}

GeRMER, W. D. (1948): Über Odeme bei Cyrenbehandlung, Dtsch. med. Wschr., 73, 280.

HurXthal, L. M., and SMITh, A. T. (1952): Treatment of Endometriosis and Other Gynæcologic Conditions with Large Doses of CEstrogens, New Engl. J. Med., 247, 339.

KenNedy, B. J., and Nathanson, I. F. (1953): Effects of Intensive Sex Steroid Hormone Therapy in Advanced Breast Cancer, $\mathcal{F}$. Amer. med. Ass., 152, 1135.

KLOPPER, A. (1959): The Effect of Estriol on Plasma Water Content, Y. Obstet. Gynoec. Brit. Emp., 66, 822.

Laragh, J. H. (I956): Mechanisms of Edema Formation and Principles of Management, Amer. F. Med., $21,423$.

PREEDY, J. R. K., and AITKEN, E. H. (1956): Effect of Estrogens on Water and Electrolyte Metabolism; Hepatic Disease, F. Clin. Invest., 35, 430 .

- (1956): Effect of Estrogens on Water and Electrolyte Metabolism; Cardiac and Renal Disease, Ibid., 35, 443.

Truelove, S. C. (1960): Stilbœestrol, Phenobarbitone and Diet in Chronic Duodenal Ulcer-A Factorial Therapeutic Trial, Brit. med. $\mathcal{F}$., ii, 559 .

Wallach, S., and Henneman, P. H. (1959): Prolonged Estrogen Therapy in Postmenopausal Women, f. Amer. med. Ass., 171, 1637.

Yates, F. E., URQUART, J., and HerbSt, A. L. (1958): Impairment of Enzymatic Inactivation of Adrenal Cortical Hormones Following Passive Venous Congestion of the Liver, Amer. F. Physiol., 194, 65. 